WARSZTATY Z GEOGRAFII TURYZMU

ISBN 978-83-7525-713-7 $\quad$ s. 67-80

http://dx.doi.org/10.18778/7525-713-7.05

Witold PÓŁTORAK, Grzegorz BIELEC

Uniwersytet Rzeszowski

\title{
PODKARPACKA KUCHNIA REGIONALNA I JEJ ZNACZENIE DLA TURYSTYKI
}

\begin{abstract}
Wstęp
Współcześnie turystyka odgrywa ważną rolę w gospodarce wielu krajów i regionów świata. Ten sektor przynosi znaczne dochody lokalnym społecznościom, a także generuje nowe miejsca pracy. Miejsca recepcji turystycznej, zarówno te posiadające renomę, jak i rozwijające się, w obliczu niezliczonej liczby konkurencyjnych ofert turystycznych, wymagają permanentnego wysublimowania już istniejących atrakcji, a także kreowania nowych produktów. Przedstawiciele branży turystycznej coraz częściej do tego celu wykorzystują rozliczne zasoby kulturowe danego regionu. W ostatnich latach zauważa się pewne tendencje także ze strony turystów, którzy interesują się produktami regionalnymi. Wśród nich są produkty kulinarne, które już z nazwy wskazują na pochodzenie $\mathrm{z}$ tradycji danego regionu lub kraju.

Usługi gastronomiczne, jako podstawowe $\mathrm{w}$ procesie planowania i organizacji imprez turystycznych, stanowią istotny element w turystyce i podróżowaniu. Na rynku emisji ruchu turystycznego aspekt kulinarny jest bowiem ważnym przeżyciem podczas trwania wielu imprez. Rozwój turystyki kulinarnej, będącej częścią turystyki kulturowej, przyczynia się do powstawania coraz to nowych obiektów, wydarzeń, a nawet szlaków tematycz-
\end{abstract}


nych. Ta forma turystyki nie ogranicza się jedynie do konsumpcji, ale wiąże się również z koniecznością poznania regionu, jego przeszłości, a także tradycji związanych z przygotowywaniem potraw.

Celem autorów niniejszego artykułu jest wykazanie znaczenia kuchni regionalnej dla rozwoju turystyki na przykładzie Podkarpacia. Oferta gastronomiczna wielu miejscowości nieposiadających szczególnych walorów turystycznych może zainteresować turystów i stać się głównym motywem ich odwiedzania. Masowość spożywania posiłków przygotowywanych w krótkim czasie, na potrzeby komercyjne przyczynia się do tego, że coraz więcej ludzi poszukuje specjałów tradycyjnej kuchni, a z nią wyjątkowych smaków. Dziedzictwo kulinarne dzięki chęciom ze strony władz lokalnych, samych producentów i mieszkańców jest wykorzystywane do kreowania wizerunku danego miejsca, a także stanowi ważny element kampanii promocyjnych miejscowości. Zdaniem autorów kuchnia regionalna Podkarpacia oraz jej tradycje i obrzędy kulinarne ze względu na swoiste zróżnicowanie i oryginalność może stanowić doskonały punkt odniesienia w momencie tworzenia atrakcji turystycznych regionu oraz kreowania jego pozytywnego wizerunku na innych rynkach emisji ruchu turystycznego.

\section{Turystyka kulinarna a potrzeby konsumenckie}

Regionalne obyczaje kulinarne zmieniły się w Europie w ciągu wieków dość znacznie, zaś rodzaje oraz skład potraw uwarunkowane były od produktów regionalnego rolnictwa, łowiectwa, rybołówstwa i dostępności na rynku. Zmianom kulinarnym $\mathrm{w}$ poszczególnych regionach często towarzyszył masowy import nowych składników oraz wprowadzania innych - nieznanych, kultur uprawy roślin. Przykładem może być import ryżu z Chin, włoszczyzna w Polsce w okresie XVI-XVII w. czy ziemniaki w Niemczech i Polsce pod koniec XVIII w. (MIKOS V. ROHRSCHEIDT 2008, s. 154). „Historia każdej narodowej diety to historia narodu wraz z jego jedzeniowymi modami, z wymyślaniem nowości i ich porzucaniem. Epizody te znaczą kartografię kolonializmu i migracji, handlu i eksploracji, wymiany kulturowej oraz zaznaczania granic" (Bell, Valentine 1997, za: WIECZOREK 2008, s. 168-169).

W Polsce dominującą rolę w zasadach żywienia, sposobach przechowywania i przyrządzania potraw odegrały warunki naturalne, klimat i gleba, warunki społeczno-gospodarcze i geograficzne. Kuchnia polska, permanentnie związana $\mathrm{z}$ historia, a także poddawana obcym wpływom, była przeo- 
brażana. Na kształt polskiej sztuki kulinarnej silnie oddziaływały również zwyczaje związane z religia, tj. posty, święta kościelne i liczne uroczystości (por. GĄSIOROWSKI 2005, s. 3-5).

W drugiej połowie XX w. zainteresowanie sposobem żywienia oraz przyrządzania potraw wzrosło wśród mieszkańców krajów rozwiniętych. Przyczyniły się do tego zmiany w stylu życia, a przede wszystkim dostosowanie posiłków do swoich obowiązków zawodowych, a także poprawa świadomości dotyczącej tzw. zdrowego i prawidłowego odżywiania się (MIKA 2007, s. 222). Dziś nadal w zamożniejszych krajach europejskich oferta wycieczek kulinarnych należy do oferty specjalnej i, jak zauważa A. Mikos von Rohrscheidt, zatraca swój elitarny charakter. Miały na to wpływ dwa czynniki: pierwszy upowszechnienie oferty światowej kuchni na miejscu, dzięki ogólnej i niezależnej od pory roku dostępności składników oraz drugi, zwiększenie się liczby turystów zapoznających się z kulturą jedzenia i picia we wszystkich zakątkach świata (MIKOS V. ROHRSCHEIDT 2008, s. 154).

Aktualnie w literaturze występuje wiele synonimów terminu „turystyka kulinarna", które wyjaśniają znaczenie i zakres pojęciowy, są to m.in. "turystyka gastronomiczna" (ang. gastronomic tourism), "turystyka smakoszy" (ang. gourmet tourism) i "turystyka tradycji kulinarnych" (ang. cusine tourism) (MIKA 2007, s. 223) ${ }^{1}$. MIKOS VON ROHRSCHEIDT (2008, s. 155-156) uważa, że „mianem turystyki kulinarnej określa się przedsięwzięcia o charakterze turystycznym, w których istotną częścią programu lub decydującym motywem podjęcia podróży jest skorzystanie z ofert kulinarnych obcego kraju lub regionu". Istotna z punktu widzenia rozwoju turystyki jest możliwość poznawania kultury ludowej i tradycji kulinarnych. Jest to możliwe na wiele różnych sposobów, np. zwiedzanie fabryk czekolady, winnic, wiejskich targowisk czy konsumpcja w karczmach regionalnych. Pomimo tego najwięcej potraw i produktów tradycyjnych można w jednym czasie i miejscu spotkać podczas różnych wydarzeń kulturalnych ${ }^{2}$, np. podczas festynów kulinarnych (por. MOKRAS-GRABOWSKA 2009, s. 24-25, MILEWSKA, PRĄCZKO, STASIAK 2010, s. 203-209).

\footnotetext{
${ }^{1}$ Pierwszy raz termin - „turystyka kulinarna" (ang. food tourism) został użyty przez Lucy Long w roku 1998 z Uniwersytetu Bowling Greek w Ohio. Coraz częściej spotykanym zjawiskiem są podróże kulinarne po danym kraju bądź regionie mające na celu odkrywanie atrakcyjności turystycznej kraju bądź regionu pod kątem kuchni regionalnej (BATYK i in. 2010, s. 296).

2 Wydarzenie, to zaplanowane i zorganizowane zdarzenie (lub zespół zdarzeń), integrujące produkty proste oraz walory turystyczne, nastawione na osiaganie korzyści w sferze psychologicznej, społecznej i gospodarczej. Posiada cechy takie, jak: duża spójność tematyczna i organizacyjna, konkretna lokalizacja w czasie i przestrzeni, niecodzienność, wyjątkowość, cykliczność (KACZMAREK, STASIAK, WŁODARCZYK 2010, s. 107).
} 
Powszechnie spośród produktów występujących na rynku dominują takie, które są masowo produkowane, wysoko przetworzone, ogólnodostępne, o międzynarodowej jakości. Konsumenci coraz częściej jednak zwracają uwagę na wartości produktów inne niż użytkowe, a mianowicie: unikatowość, styl, oryginalność, walor emocjonalny czy pochodzenie. W krajach Unii Europejskiej dba się szczególnie o rynek takich produktów. Są one swoistą wizytówką i marką regionu, a ich receptura oraz sposób przygotowywania podlegają szczególnej ochronie. Umiejętne określenie handlowej jakości powszechnie znanych tradycyjnych produktów, ochrona wiedzy oraz sposobu wytwarzania mogą przynieść uznanie i stanowić dodatkowe źródło dochodu. Często dany region właśnie dzięki takim produktom jest rozpoznawany. $W$ tej sytuacji Polska ma szansę zająć prestiżowe miejsce wśród liderów rynku żywności wysokiej jakości. Zróżnicowane dziedzictwo kulinarne spowodowane bogatym dorobkiem kulturowym jest szansą na wyróżnienie się Polski pośród innych krajów. Do wytwarzania tych produktów wykorzystuje się bowiem unikatowe rasy zwierząt i ich naturalny sposób hodowli, nietypowe uprawy, czy też dawne odmiany roślin oraz tradycyjne technologie przetwarzania.

\section{Produkty regionalne Podkarpacia}

Kuchnia regionalna to jeden z typowych wyznaczników, które wyróżniają regiony w Polsce. W chwili obecnej (stan na 15.05.2011 r.) na Liście Produktów Tradycyjnych ${ }^{3}$ znajdują się 854 produkty. $Z$ roku na rok rejestrowane są nowe wyroby, a potencjał kulinarny poszczególnych regionów dynamicznie wzrasta. Najwięcej produktów pochodzi z województw: śląskiego, pomorskiego i podkarpackiego. Stanowią one 1/3 wszystkich wpisów znajdujących się na tej liście (rys. 1).

Produkty wpisywane na Listę Produktów Tradycyjnych muszą być wytwarzane przez co najmniej 25 lat i mogą zostać sklasyfikowane w dziesięciu kategoriach. Na krajowej Liście Produktów Tradycyjnych największą liczbę

\footnotetext{
${ }^{3}$ Krajowa Lista Produktów Tradycyjnych została utworzona na mocy Ustawy z dnia 17 grudnia 2004 r. o rejestracji i ochronie nazw i oznaczeń produktów rolnych i środków spożywczych oraz o produktach tradycyjnych. Pozwala ona na: identyfikację produktów tradycyjnych, propagowanie kultury i tradycji, zwiększenie świadomości konsumentów co do istoty produktów tradycyjnych, przygotowanie producentów do rejestracji na liście międzynarodowej, stworzenie możliwości ubiegania się o odstępstwa weterynaryjne i sanitarne przy produkcji żywności, dywersyfikację zatrudnienia na obszarach wiejskich, wzrost atrakcyjności regionu.
}

70 WARSTATYZ GEOGRAFII TURYZM 


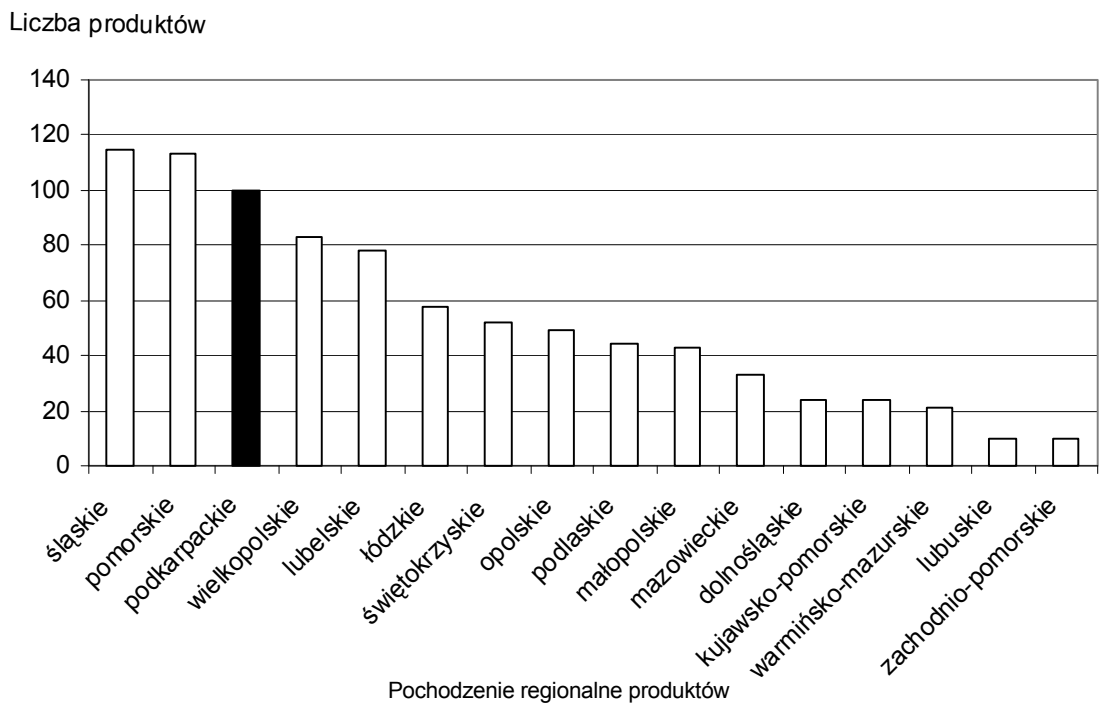

Rys. 1. Liczba produktów regionalnych znajdujących się na krajowej Liście Produktów Tradycyjnych Źródło: opracowanie własne na podstawie danych z www.minrol.go.pl (10.05.2011)

stanowią dania gotowe, wyroby piekarnicze i produkty mięsne. Stanowią one $61 \%$ wszystkich specjałów. Oleje i tłuszcze oraz inne produkty są najmniej licznymi kategoriami wśród wszystkich produktów wpisanych na listę (tab. 1).

Tabela 1. Liczba produktów tradycyjnych wg kategorii w Polsce i woj. podkarpackim

\begin{tabular}{|l|c|c|}
\hline \multirow{2}{*}{\multicolumn{1}{|c|}{ Kategoria }} & \multicolumn{2}{c|}{ Liczba produktów } \\
\cline { 2 - 3 } & w Polsce & w woj. podkarpackim \\
\hline Produkty mleczne & 65 & 8 \\
\hline Produkty mięsne & 161 & - \\
\hline Produkty rybołówstwa & 21 & 9 \\
\hline Warzywa i owoce & 89 & 21 \\
\hline Wyroby piekarnicze & 172 & - \\
\hline Oleje i tłuszcze & 19 & 3 \\
\hline Miody & 38 & 21 \\
\hline Gotowe dania & 186 & 7 \\
\hline Napoje & 88 & - \\
\hline Inne & 17 & 100 \\
\hline Razem & 856 & \\
\hline
\end{tabular}

Źródło: opracowanie własne na podstawie z www.minrol.go.pl (10.05.2011) 
W województwie podkarpackim zarejestrowano 100 produktów tradycyjnych. Najbardziej licznymi grupami są produkty mięsne, wyroby piekarnicze oraz gotowe dania i potrawy. Lista Produktów Tradycyjnych zawiera produkty, które łączą $\mathrm{w}$ sobie tradycje i fragment historii regionu, z którym kojarzy się dana potrawa czy też wzbudza zainteresowanie wśród konsumentów. W tab. 2 przedstawiono specyficzne dla podkarpackiej kuchni gotowe dania i potrawy, natomiast szczegółowy wykaz produktów tradycyjnych znaleźć można na stronie internetowej Ministerstwa Rolnictwa i Rozwoju Wsi (z www.minrol.go.pl, 10.05.2011).

Tabela 2. Podkarpacka Lista Produktów Tradycyjnych - gotowe dania i potrawy

\begin{tabular}{|l|c|}
\hline \multicolumn{1}{|c|}{ Nazwa produktu } & Data rejestracji \\
\hline Pieróg dachnowski z kaszą gryczaną i ziemniakami & 09.09 .2009 \\
\hline Maczka z gęsi po dachnowsku & 18.09 .2009 \\
\hline Gołąbki z Nowego Sioła & 18.09 .2009 \\
\hline Pamuła glinicka & 31.07 .2009 \\
\hline Razowe pierogi z Wiercan & 19.12 .2008 \\
\hline Żur rzeszowski & 04.09 .2007 \\
\hline Kapusta ziemniaczana & 04.05 .2007 \\
\hline Gołąbki pilzneńskie & 30.01 .2007 \\
\hline Pierogi ruskie pilzneńskie & 30.01 .2007 \\
\hline Pierogi z mięsem pilzneńskie & 30.01 .2007 \\
\hline Pierogi z kapustą i grzybami pilzneńskie & 30.01 .2007 \\
\hline Pierogi pilzneńskie z borówkami & 30.01 .2007 \\
\hline Kapusta z kaszą jęczmienną po lasowiacku & 19.07 .2006 \\
\hline Kacapoły lub klgle & 19.07 .2006 \\
\hline Panepuchy & 19.07 .2006 \\
\hline Pierogi z kaszy jaglanej z serem & 09.03 .2010 \\
\hline Kwas z gąsek zielonych & 09.03 .2010 \\
\hline Handzlowska serwatka wielkanocna & 19.08 .2010 \\
\hline Kapusta wigilijna po Pysznicku & 19.08 .2010 \\
\hline Studzionka bobowo-serowa & 19.08 .2010 \\
\hline Pieczone pierogi św. Jacka & 19.08 .2010 \\
\hline
\end{tabular}

Źródło: opracowanie własne na podstawie z www.minrol.go.pl.

\section{Metodologia badań}

Celem badań było wykazanie atrakcyjności oferty kulinarnej regionu i jej znaczenia dla turystyki na przykładzie województwa podkarpackiego. Prob-

72 WARSTAATY Z GEOGPAFII TURYZN 
lem badawczy stanowiła odpowiedź na pytanie: Jakie znaczenie dla turystyki na Podkarpaciu ma kuchnia regionalna? Postawiono też następujące hipotezy, a mianowicie:

- kuchnia regionalna podwyższa atrakcyjność turystyczną regionu i niesie ze sobą perspektywy jego rozwoju,

- dziedzictwo kulinarne znacząco wpływa na rozwój turystyki na Podkarpaciu i jest przyczyną zainteresowania regionem.

Badania przeprowadzono na wiosnę 2011 r. w miejscowościach Bachórz koło Dynowa (droga krajowa Rzeszów-Przemyśl) i Krasne (droga międzynarodowa Łańcut-Rzeszów). W obu tych miejscowościach znajdują się stylowe karczmy serwujące specjalności kuchni regionalnej Podkarpacia. Zdaniem BATYKA i in. (2010, s. 297), obiektami, w których gość, klient lub turysta może poczuć indywidualny charakter regionu są: stylowe karczmy, zajazdy, gospody, restauracje z długoletnią tradycją.

W badaniach brały udział osoby wybrane celowo. Pierwszym etapem przeprowadzenia badań było wyłonienie uczestników imprezy turystycznej wśród wszystkich klientów przebywających w obiekcie gastronomicznym. Do badań wykorzystano sondaż diagnostyczny. Zastosowano kwestionariusz ankiety składający się z 18 pytań o charakterze zamkniętym. Respondenci zostali powiadomieni o celach badań oraz ich anonimowości. W kwestionariuszu zawarto pytania na temat motywów podejmowania wyjazdów turystycznych, znajomości kuchni regionalnej Podkarpacia, a także uzyskano opinie dotyczące istotności dziedzictwa kulinarnego w procesie kształtowania się atrakcyjności kulinarnej i turystycznej regionu. Na wstępie kwestionariusza umieszczono metryczkę zawierającą pytania dotyczące płci, wieku oraz miejsca zamieszkania. Ogółem w badaniu wzięło udział 100 osób (58 kobiet i 42 mężczyzn), które zostały ujęte w następujące kategorie wiekowe: poniżej 18 lat (18\%), od 19 do 30 lat (25\%), od 31 do 40 lat (22\%), od 41 do 50 lat $(20 \%)$ i powyżej 51 lat (18\%). Miejscem zamieszkania zdecydowanej większości badanych (65\%) było miasto, pozostała część zamieszkiwała tereny wiejskie. Niespełna $2 / 3$ respondentów pochodziła z województwa podkarpackiego, pozostali wskazali inne województwo.

\section{Wyniki}

W pierwszym pytaniu respondenci zostali poproszeni o podanie właściwego określenia dla terminu „kuchnia regionalna”. Spośród kilku możliwych ankietowani najczęściej wybierali odpowiedzi: „potrawy związane bądź występujące wyłącznie na określonym obszarze” (48\%) oraz „potrawy przygoto- 
wane według tradycyjnych przepisów" (31\%). Pozostali badani uważali, że kuchnia regionalna to: produkty i potrawy znajdujące się na Liście Produktów Tradycyjnych $(14 \%)$ oraz potrawy przygotowane z produktów pochodzenia naturalnego (żywność ekologiczna) (7\%).

W pytaniu o motywy, jakimi kierują się przy planowaniu wyjazdów turystycznych, poproszono o wskazanie czterech $\mathrm{z}$ siedmiu sugerowanych odpowiedzi. Najczęstszymi motywami przewodnimi podróży były: „możliwość wypoczynku i relaksu” (25\%), „zwiedzanie atrakcji” (21\%), „poznanie kultury, tradycji odwiedzanego miejsca w tym kuchni regionalnej" $(15 \%)$, "udział w imprezach, koncertach, festiwalach" (14\%), „odwiedziny krewnych i znajomych” (11\%), „możliwość uprawiania sportów” (10\%) oraz inne (4\%).

W Polsce można wyróżnić regiony, które posiadają odrębne, charakterystyczne tylko dla nich kuchnie regionalne. W związku z powyższym badanych zapytano, jakie kuchnie regionalne w Polsce są im znane? Ankietowani mieli możliwość wyboru kilku odpowiedzi, a także udzielenia innej - własnej. Ponad połowa zebranych odpowiedzi dotyczyła: kuchni podhalańskiej (36\%) oraz kuchni kaszubskiej i pomorskiej (24\%). Kuchnia podkarpacka wskazana została przez $16 \%$ badanych. Rzadziej wybierano kuchnię małopolską (10\%) oraz Warmii i Mazur (9\%). W odpowiedziach „inne” znalazły się: kuchnia śląska i pomorska (5\%).

Kuchnia regionalna na Podkarpaciu składa się z wielu potraw i produktów przygotowywanych zgodnie $z$ tradycją i według przepisów przekazywanych przez pokolenia. Część z nich znajduje się na Podkarpackiej Liście Produktów Regionalnych i w starych książkach kucharskich oraz są serwowane w karczmach i zajazdach lub do dziś na rodzinnych stołach. Ankietowani w pytaniu dotyczącym znajomości potraw podkarpackiej kuchni regionalnej mieli możliwość wyboru sugerowanych odpowiedzi, a także udzielenia własnej. Wyniki udzielonych odpowiedzi ilustruje rys. 2.

Ponad $3 / 4$ badanych deklarowało, że wcześniej zetknęli się z potrawami lub produktami kuchni regionalnej Podkarpacia, jednak co trzecia osoba nigdy nie spożywała tych specjałów. Ankietowanych, którzy nie jedli wcześniej potraw $\mathrm{z}$ podkarpackiej kuchni regionalnej zapytano o ich powody. W tym przypadku co druga osoba twierdziła, że kuchnia regionalna jest mało dostępna, ale były też inne odpowiedzi, np. nie wiedziano o jej istnieniu, jest niezdrowa oraz inne, nie podając konkretnych powodów (rys. 3).

Najlepszym działaniem $\mathrm{w}$ celu rozpowszechniania kuchni regionalnej wśród turystów jest jej promocja. Opinie respondentów na temat stanu promocji dziedzictwa kulinarnego na Podkarpaciu były podzielone. Ponad $1 / 3$ ankietowanych twierdziła, że kuchnia regionalna jest promowana dobrze, natomiast zgoła odmiennego zdania było $27 \%$ badanych (rys. 4 ).

74 WARSTATYZ GEOGRAFII TURYZM 


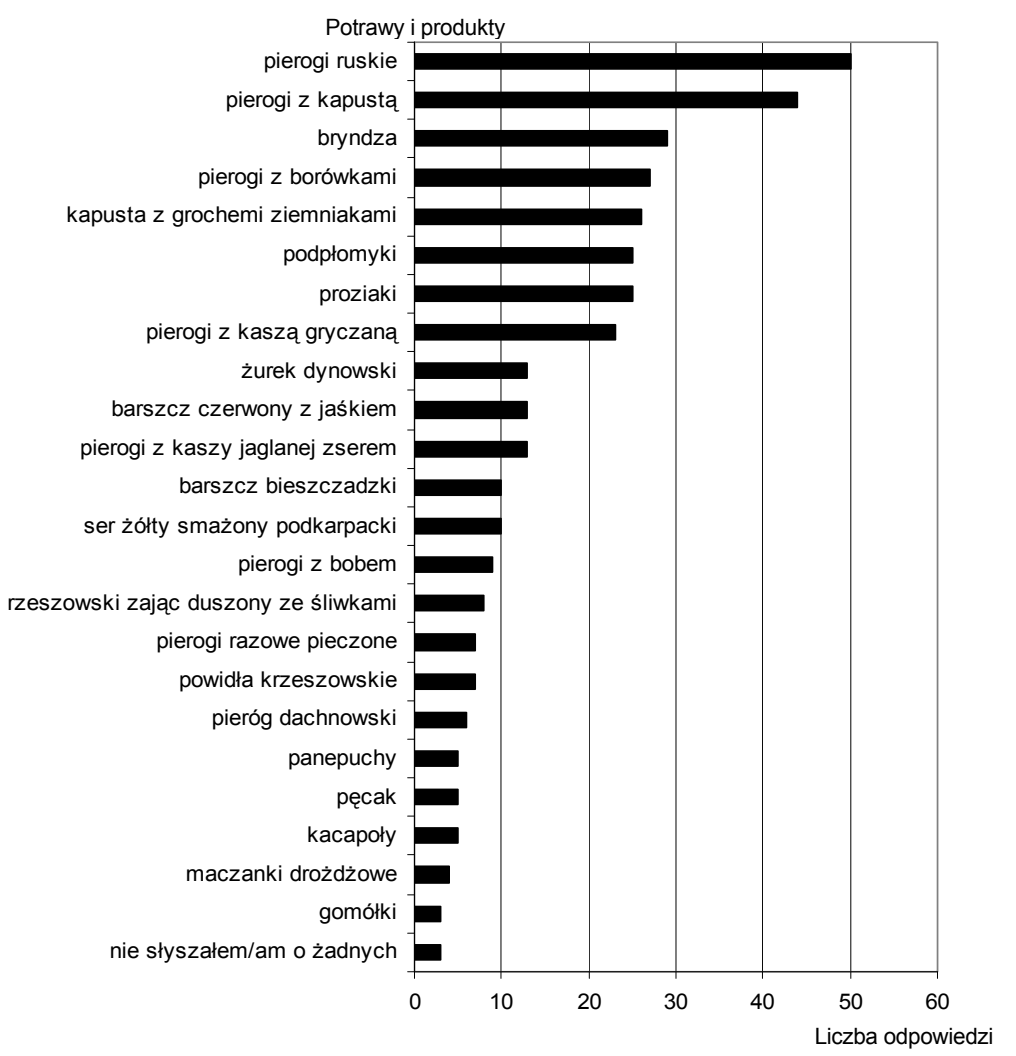

Rys. 2. Znajomość produktów i potraw kuchni regionalnej Podkarpacia przez ankietowanych Źródło: opracowanie własne

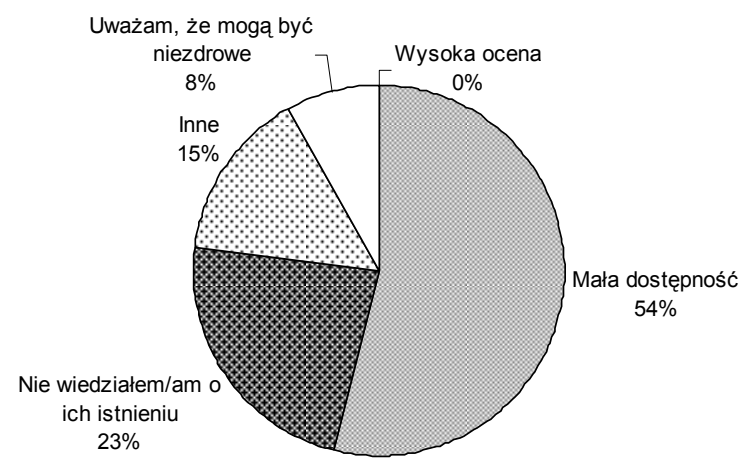

Rys. 3. Bariery w spożywaniu produktów i potraw kuchni regionalnej Podkarpacia według respondentów

Źródło: opracowanie własne 


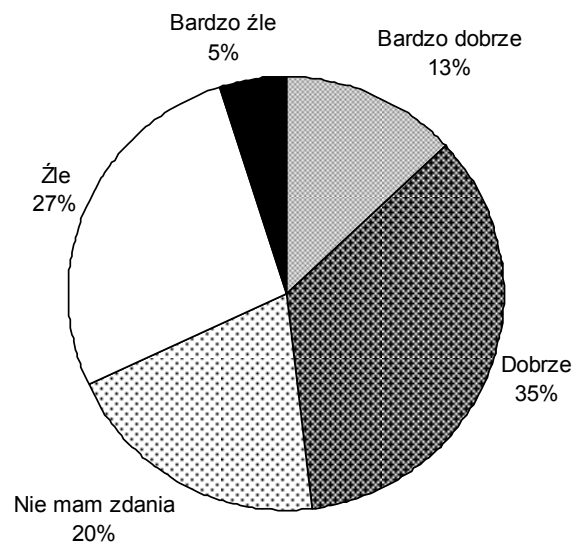

Rys. 4. Ocena promocji podkarpackiej kuchni regionalnej według ankietowanych Źródło: opracowanie własne

Z kolejnych pytań wynika, że aż 90\% badanych osób uważa, że kuchnia regionalna ma istotne znaczenie dla regionu, a dla Podkarpacia szczególne i może stać się jego wizytówką. Niemalże wszyscy respondenci uważają również, że w oparciu o podkarpacką kuchnię regionalną można kreować produkt turystyczny, który stworzyłby ciekawą ofertę dla turystów odwiedzających region. Zaledwie 18\% badanych nie postrzega kuchni jako mocnej strony oferty turystycznej.

Odzwierciedlenie wyników dotyczących stworzenia oferty turystycznej w oparciu o produkty i potrawy kuchni regionalnej uzyskano w odpowiedzi na pytanie o idee stworzenia kulinarnego szlaku turystycznego. Zdecydowana większość ankietowanych była za promowaniem już istniejących szlaków dziedzictwa kulinarnego oraz tworzeniem nowych. Jedynie $18 \%$ było przeciwnych wyznaczaniu takowych tras.

Innymi produktami turystycznymi, które tworzy się w oparciu o zasoby dziedzictwa kulinarnego regionu oraz tradycji kulinarnych są festiwale, konkursy, targi itp. Ponad $1 / 3$ badanych osób deklarowało, że nigdy nie uczestniczyło w imprezach regionalnych na Podkarpaciu organizowanych w celu promocji żywności regionalnej. Respondentów, którzy nie uczestniczyli w imprezach regionalnych o charakterze kulinarnym zapytano o przyczyny. $42 \%$ ankietowanych uważa, że festiwale, targi, festyny itp. są słabo reklamowane przez organizatorów i władze lokalne, 33\% obwinia o brak cykliczności oraz $13 \%$ o słabą organizację. Pozostali badani twierdzili, że nie są zainteresowani kuchnią regionalną oraz że program tego typu imprez jest mało interesujący (rys. 5). 


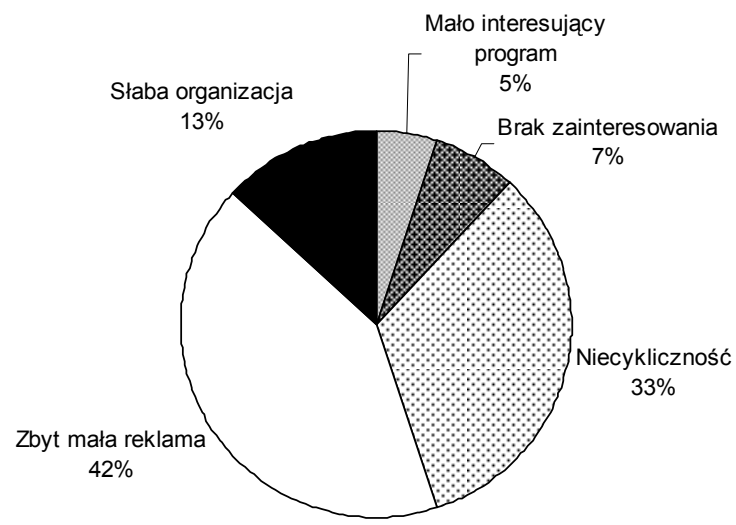

Rys. 5. Opinie badanych na temat zainteresowania imprezami regionalnymi Źródło: opracowanie własne

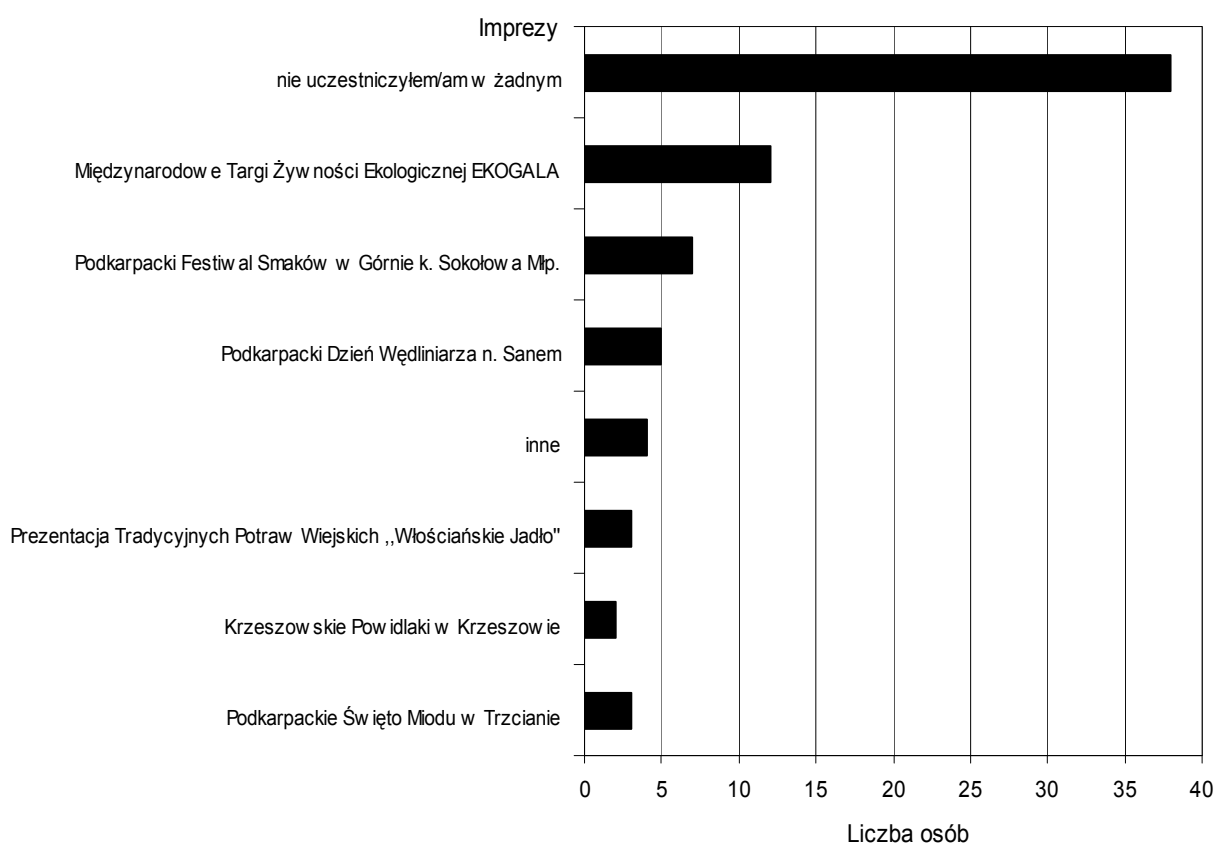

Rys. 6. Uczestnictwo badanych w imprezach regionalnych wykorzystujących kuchnię regionalną Źródło: opracowanie własne

W ofercie imprez regionalnych województwa podkarpackiego zorganizowanych w oparciu o kuchnię regionalną można spotkać wiele propozycji. 
Respondenci, którzy brali udział w imprezach regionalnych uczestniczyli w: Międzynarodowych Targach Żywności „Ekogala” w Rzeszowie, Podkarpackim Festiwalu Smaków w Górnie, Podkarpackim Dniu Wędliniarza w Rudniku nad Sanem, Prezentacji Tradycyjnych Potraw Wiejskich Włościańskie Jadło, Krzeszowskich Powidlakach, Podkarpackim Święcie Miodu w Trzcianie, Święcie Chleba w Dźwiniaczu Dolnym oraz Festiwalu Kultur i Kresowego Jadła w Baszni Dolnej. Uczestnictwo respondentów w tych imprezach ilustruje rys. 6 .

\section{Podsumowanie i wnioski}

Z prezentowanych wyników badań wynika, że turyści zatrzymujący się w obiektach gastronomicznych serwujących regionalne potrawy często świadomie poszukują tradycyjnych regionalnych smaków w odpowiednich produktach i potrawach. Przekonuje o tym fakt, że respondenci właściwie pojmują znaczenie terminu "kuchnia regionalna”. Przebywając w stylowych zajazdach, gospodach poznają kulturę, tradycję odwiedzanego miejsca, w tym kuchnię regionalna, a także sposób przygotowywania i serwowania regionalnych potraw. Niniejsze badania dowodza, że Podkarpacie dysponuje dużym potencjałem kulinarnym, mogącym przyciagnąć turystów. Jednak podkarpacka kuchnia regionalna nie jest aż tak znana i rozpoznawalna chociażby jak kuchnia podhalańska, kaszubska czy pomorska.

Warto zaznaczyć, że pomimo potencjału, jaki niesie dziedzictwo kulinarne, nie jest ono wystarczająco docenione przez władze lokalne. Ankietowani uważają że podkarpacka kultura i tradycja, w tym również jej kuchnia regionalna, są mało dostępne na rynku towarów i usług turystycznych. Brak informacji i promocji na jej temat okazuje się znaczącą barierą rozwoju turystyki kulinarnej na Podkarpaciu. Brak cykliczności organizowanych imprez kulinarnych, jak również nieefektywna promocja organizowanych wydarzeń kulinarnych, a także ich mało ciekawy program - szczególnie dla młodszych uczestników - skutkują tym, że ten rodzaj turystyki nie rozwija się zbyt dynamicznie.

Miejsce recepcji turystycznej $\mathrm{w}$ obliczu niezliczonych ofert turystycznych, powinno uatrakcyjniać swoją ofertę, często wykorzystując zasoby kulturowe. Oczywiste jest, że w miejscowościach atrakcyjnych turystycznie zdecydowanie łatwiej jest wypromować kuchnię regionalną. Towarzyszy temu niekiedy doskonale rozwinięta baza turystyczna oraz infrastruktura komunikacyjna. Zadaniem o wiele trudniejszym jest wypromowanie gastronomii lo- 
kalnej i stworzenie z niej głównej atrakcji turystycznej. Niemniej jednak z całą pewnością stwierdzić można, że w dzisiejszym świecie konsumpcji i masowej produkcji dziedzictwo kulinarne i z nim związane tradycje są wyjątkowym dobrem, które należy odpowiednio pielęgnować i promować. W związku z powyższym nasuwają się konkretne wnioski dla władz głoszących politykę turystyczną państwa, a także dla przedstawicieli samorządów lokalnych Podkarpacia zajmujących się promocją turystyki w Polsce i za granicą. Turystyka $\mathrm{w}$ tym regionie rozwijać się będzie w oparciu o szeroko pojmowane dziedzictwo kulturowe, jego różnorodność i specyfikę swoistą dla Podkarpacia, $\mathrm{w}$ tym również o autentyczna, tradycyjna, regionalną, a przede wszystkim dobrą kuchnię. Turystyka w tym regionie stawać się będzie coraz bardziej znaczącym źródłem dochodu oraz wsparciem dla powiązanych z nią usług, rolnictwa czy przemysłu, zaś inwestycje turystyczne przyczynią się do rozwoju infrastruktury i transportu, a tym samym nieść będzie dalsze korzyści dla mieszkańców Podkarpacia.

Niemal wszyscy respondenci uważaja, że za sprawą potencjału oraz możliwości kultury i tradycji kulinarnych Podkarpacia można stworzyć atrakcyjny produkt turystyczny przyciągający turystów i odwiedzających, miłośników smaku, a także wzbogacić już istniejącą ofertę turystyczną. Mógłby on być wizytówką regionu i wpłynąć na jego turystyczny rozwój bardziej niż dzieje się to $\mathrm{w}$ innych częściach Polski. W tym celu konieczne jest udanie się $\mathrm{w}$ podróż po regionie.

Przeprowadzone badania i ich analiza dowiodły, że kuchnia regionalna istotnie zmienia wielkość ruchu turystycznego. Turyści chętnie uczestniczą $\mathrm{w}$ wyjazdach w celu poznania kultury i tradycji odwiedzanego miejsca, ze szczególnym uwzględnieniem autentyczności kuchni regionalnej. Ostatnio obserwuje się bowiem wzmożoną aktywność turystyczną Polaków oraz większą liczbę przyjazdów zagranicznych turystów korzystających z walorów przyrodniczo-krajobrazowych oraz smakujących polską tradycyjną kuchnię. Obserwowana moda na Polskę zwiększa szanse województwa podkarpackiego na rynku europejskim. Jednocześnie zobowiązuje do kreowania atrakcyjnego produktu turystycznego, stwarzania ciekawych ofert żywieniowych głównie przez obszary wiejskie, w oparciu o tradycyjne produkty kuchni regionalnej, przygotowywane na bazie lokalnych surowców.

\section{BIBLIOGRAFIA}

BATYK I. M., ESKTEROWICZ J., NAPIERAŁA M., MusZKIETA R., ZUKOW W., 2010, Wybrane aspekty turystyki kulinarnej w odniesieniu do gospodarstw agroturystycznych Warmii i Mazur, [w:] 
R. Muszkieta (red.), Rehabilitation and tourism activity - key issues, University of Economics, Bydgoszcz.

GĄSIOROWSKI M., 2005, O produktach tradycyjnych i regionalnych. Możliwości a polskie realia, Fundacja Fundusz Współpracy, Warszawa.

KaczMareK J., Stasiak A., WŁodArczyK B., 2010, Produkt turystyczny. Pomyst, organizacja, zarzadzanie, Polskie Wydawnictwo Ekonomiczne, Warszawa.

MiKa M., 2007, Formy turystyki poznawczej, [w:] W. Kurek (red.), Turystyka, Wydawnictwo Naukowe PWN, Warszawa.

MiKOS VON ROHRSCHEIDT A., 2008, Turystyka Kulturowa. Fenomen, potencjat, perspektywy, Wydawnictwo KMB Druk, Gniezno.

MilewSKa M., PrąCZKO A., StASIAK A., 2010, Podstawy gastronomii, Polskie Wydawnictwo Ekonomiczne, Warszawa.

MOKRAS-GRABOWSKA J., 2009, Możliwości rozwoju turystyki kulturowej obszarów wiejskich w Polsce. Turystyka kulturowa, www.turystykakulturowa.org.

WiECZORKIEWICZ A., 2008, Apetyt turysty. O doświadczeniu świata w podróży, TAiWPN Universitas, Kraków.

www.minrol.gov.pl (10.05.2011).

80 WARSZTATY Z GEOGRAFII TURYZMU 